\title{
UNEMPLOYMENT AND RESERVATION WAGES IN WORKING-CLASS CAPE TOWN
}

\author{
NICOLI NATTRASS ${ }^{*}$ AND RICHARD WALKER ${ }^{* *}$
}

\section{Abstract}

Are the unemployed in South Africa 'pricing themselves out of the labour market;? This paper explores this proposition through an analysis of reservation wages in Cape Town's working class district of Khayelitsha/Mitchell's Plain. It argues that reservation wages are not out of line with predicted wages. This, in turn, suggests that unemployment in the area is not attributable to job seekers having unrealistically high reservation wages.

\section{INTRODUCTION}

Unemployment is a major problem in South Africa. According to the September 2003 Labour Force Survey, South Africa's unemployment rate was 28.2\% (including only active job seekers) and $41.8 \%$ (if discouraged job seekers are included). As no significant welfare provision is available for adults of working age in South Africa, it is unsurprising that there is a strong correlation between unemployment, inequality and poverty (Leibbrandt et al, 2001, Leibbrandt and Woolard, 2001; Seekings, 2003a 2003b; Seekings and Nattrass, 2005 forthcoming).

There is, however, some suspicion that measured unemployment is simply too high to be believable (see e.g. Standing et al, 1996 and a review of the debate in Nattrass, 2000). Two persistent concerns are that labour-market surveys must somehow be counting as 'unemployed' people who really are working, and/or including as unemployed those who have 'priced themselves out of the market' by setting their reservation wages (i.e. the lowest wage they would be prepared to accept) unrealistically high.

This paper sheds light on this issue by using data from a representative survey of the Khayelitsha/Mitchells Plain (KMP) Magisterial District in Cape Town. The KMP survey was conducted in 2000/1 amongst 1,176 households and 2,644 adults (the survey sought to interview every person aged 18 years or older in each household - see Crankshaw et al, 2001 for details on the sampling methodology). Of the surveyed individuals, 69\% were African, 30\% were Coloured (mixed race) and the remaining 1\% comprised insignificant numbers of white and Indian people. Only African and Coloured respondents are included in this analysis.

The KMP survey was designed specifically to explore various dimensions of labourmarket attachment and behaviour (Nattrass, 2002). It covered the predominantly Coloured area of Mitchell's Plain and the African townships of Khayelitsha, Gugulethu and Langa. It is thus not a representative sample of the Cape Town metropolitan area but rather of working class (predominantly African and Coloured) Cape Town. The data set is available for public use in the Data First Resource Centre in the Centre for Social Science Research at the University of Cape Town.

This paper starts off with a discussion of the measurement and definition of

\footnotetext{
* Professor, Dept of Economics, UCT.

** Researcher, Centre for Social Science Research, UCT.
}

The authors would like to thank two anonymous referees for their comments. 
unemployment made possible by the KMP data. This is followed by an analysis of reservation wages and the factors influencing them. The final section presents an exploratory analysis of the relationship between reservation wages and predicted wages. It suggests that reservation wages are not out of line with predicted wages. This, in turn, suggests that unemployment in working class Cape Town is not attributable to job seekers having unrealistically high reservation wages.

\section{UNEMPLOYMENT IN KMP}

The international standard labour force approach (as developed by the International Conference of Labour Statisticians (ICLS) - see below) allocates all individuals above a certain minimum age to one of three mutually exclusive and exhaustive labour-market categories: the employed (defined as people engaged in productive activity either for the market or their own consumption for an hour or more a week); the unemployed (those wanting and seeking work); and non-labour-force participants. This is done according to a set of priority rules which first identify the employed, then the unemployed, and finally the non-labour-force participants (i.e. the residual). In terms of this approach, someone who describes him or herself as unemployed and looking for work, but who also reports that he or she has engaged in some productive activity during the given reference period, will be classified as employed rather than unemployed.

In terms of the labour force approach codified by the (ICLS)), the unemployed comprise those above a certain minimum working age who are 1) 'without work' (i.e. have not been classified as 'employed'); 2) are 'currently available for work' (either paid employment or self-employment during the reference period); and 3) are 'seeking work' i.e. had 'taken specific steps in a specified recent period to seek paid employment or self-employment' (ICLS, 1982, par. 10). People satisfying these three criteria fall into the 'strict' or 'narrow' international standard definition of unemployment. It is worth noting that seeking work is understood fairly broadly to include: taking specific steps to find work which may include 'registration at a public or private employment exchange; application to employers; checking at worksites, farms, factory gates, market or other assembly places; placing or answering newspaper advertisements; seeking assistance of friends or relatives; looking for land, building, machinery or equipment to establish own enterprise; arranging for financial resources; applying for permits and licences, etc.' (ibid, par. 10.1.c).

An alternative 'broad' or 'expanded' definition of unemployment drops the third requirement - i.e. that the unemployed must be seeking work. The ICLS notes that this broader definition may be appropriate in situations where the conventional means of seeking work are of limited relevance, where the labour market is largely unorganised or of limited scope, where labour absorption is, at the time, inadequate or where the labour force is largely self-employed' (ibid, par. 10.2).

Both the strict and broad definitions require that the unemployed person be 'available' for work. This is typically understood as referring to when the person could take up the job - and /or what hours they are prepared to work. However, the ICLS suggests that 'appropriate tests' may be developed to explore the nature of availability. When labour-market conditions indicate that a broad notion of unemployment is most suitable: 'Such tests may be based on notions such as present desire for work and previous work experience, willingness to take up work for wage or salary on locally prevailing terms, or readiness to undertake self-employment activity given the necessary 
resources and facilities' (par. 14.4).

By suggesting that one could test to see whether a person will accept a job at a particular wage, the ICLS is opening the door for a greater consistency between the labour force approach to labour supply, and the conventional economic theory of labour supply as a positive function of the wage (Nattrass, 2002). However, such tests are more easily suggested than implemented. An obvious problem is that in the real world there is no single 'prevailing' wage. Indeed, prevailing wages are likely to vary across regions, across industries and across different skill bands.

The KMP survey was designed in part to explore, and expand on, the different ways of measuring unemployment discussed above. It probed different kinds of work (whether paid or unpaid), job search behaviour and reservation wages (see Nattrass, 2002 for more detail).

Following the standard international labour force approach, the first step was to allocate employment status to those who reported engaging in productive activities. Over three quarters of those who could be classified as 'working' in this way were regular, full-time wage workers (Nattrass, 2002: 7-10), the rest were casual or part-time workers.

The next step was to define the unemployed. In this regard, the standard labour force approach was adapted to take into account the possibility that jobless individuals may have decided that searching for employment is best done through networks - i.e. relying on friends and relatives to find them jobs - rather than seeking their help or other forms of 'active' job search. If it is common for people to obtain work through social networks, and if it is taken for granted that friends and relatives will keep an active look-out for jobs for others (even when not specifically asked to do so), then what might appear to be a passive response - i.e. doing nothing but rely on others should rather be re-examined in a different light. As there is a growing body of South African literature showing the importance of this method of job search (see e.g. Baber, 1998; Wittenberg, 1999; Dinkelman and Pirouz, 2001; Wittenberg, 2001; Seekings 2003; Dinkelman, 2004; Duff and Fryer, 2004; Schöer, 2004), such an approach is certainly worth pursuing.

The KMP data set allows us to create three new definitions of unemployment: (1) the active-searching unemployed; (2) the network-searching unemployed; and (3) the marginalised unemployed. Definition 1 amounts to the strict definition of unemployment, and definitions 2 and 3 together comprise the broad definition.

To qualify as an active-searching unemployed person, the respondent must not already be defined as 'employed' (as described above); must report that he/she wants a job and is available for work during week days; and has searched actively for work (Nattrass, 2002: 11-12).

'Exclusive network searchers' are defined here as those who are available and willing to work, are not taking active steps to find it, but are rather relying on friends and relatives to find them work, or to tell them about job opportunities (ibid: 12).

The marginalised unemployed are defined as those who are ready and willing to work, but do not qualify either as active job seekers or as network job-searchers. They are thus, in an important sense, 'marginalised' from (or in Dinkelman and Pirouz's (2001) terms, they may be said to be less 'attached' to) the labour market. One may call such individuals 'discouraged' job seekers - but as that implies (perhaps) some knowledge of their psychological states, this category has simply been labelled as the 
'marginalised unemployed'.

In terms of the above definitions, the unemployment rate in KMP ranges from $28.4 \%$ (strict definition including only the active job seekers) to $35.5 \%$ (intermediate definition including active job seekers and those relying on networks) and 46.3\% (including active job seekers, those relying on networks and the marginalised unemployed).

\section{RESERVATION WAGES}

A first step in exploring whether unemployed people are 'pricing themselves out of the labour market' is to examine their reservation wages - i.e. the highest wage at which they would rather 'choose leisure' or continued job search rather than work (Killingsworth, 1983; Sapsford and Tzannatos, 1993).

The notion of a reservation wage is simple conceptually, but difficult to measure in practice (see overview of international studies in Walker, 2003). It is also difficult to learn 'lessons' from international studies because the socio-economic context profoundly affects reservation wages. Most obviously, one would expect people to have higher reservation wages when unemployment and other welfare benefits are available as is the case in Great Britain (e.g. Jones, 1988). In South Africa's case, the reservation wage is more likely to be affected both by the respondent's perception of their labourmarket value and the degree of desperation they are experiencing for work.

There have been several previous attempts to measure reservation wages. Using the 1993 SALDRU survey, Kingdon and Knight (2001) assess the difference between reservation wages and predicted wages as a possible route to understanding the nature of South African unemployment. They generated predicted wages for the unemployed using parameters from the wage functions of employed persons. Their results suggest that about $50 \%$ of unemployed people have reservation wages that exceed their predicted wages - and for about $30 \%$ of the unemployed, reservation wages exceed predicted wages by more than $40 \%$. Higher reservation wages than predicted wages were especially common amongst African respondents, people from rural homelands, less-educated workers, females, the young and people who had never worked before.

Kingdon and Knight are, however, suspicious of these results and list several reasons why the reported reservation wages in the SALDRU survey may be unreliable. They criticise the survey questions as being too open to wide interpretation and speculate that respondents may be reporting their beliefs about a 'fair' wage (or a wage they would start bargaining at) rather than a genuine reservation wage.

In trying to improve the reliability of recording reported reservation wages, Dias suggests that survey questions should be reformulated as follows:

"If a full-time job is offered to ...name... nearby (within 5 kilometres of your residence) would ...name...accept it if the weekly rate were: (with a range of income categories having been provided)?" (2002:18).

She also argues that a question should be asked pertaining to the minimum wage that a respondent would accept for doing a casual job as this will help shed light on the extent to which "job security can be traded for income" (ibid, 2002:18). A further suggestion is that information should be collected on past wages or past wage offers rejected. As Dias puts it, "past wages earned may well form a reasonable benchmark for wage expectations while past wage offers rejected may substantiate the reservation wage 
reported" (2002:18).

The KMP survey had already moved in the direction suggested by Dias (although the income range idea and the five kilometre rule was not adopted) - but it went one step further by asking respondents about their reaction to specific jobs that were actually available in the area. In this regard, it was following the suggestion from the ICLS (1982, par.14.4) that appropriate 'tests' be included in surveys to understand labourmarket behaviour.

\section{RESERVATION WAGES IN KMP}

The KMP survey asks several questions about reservation wages (see Table 1), but not all respondents answered all questions as some were aimed at specific sub-samples - e.g. the employed, non labour force participants etc. All respondents answered question K5: "What is the absolute lowest monthly take home wage that you would accept for any work (if you were unemployed at the time)?" Questions F24 and F25 were for the unemployed only, question G29 was for the self-employed, and I5 and I18 were for those who reported having done some casual work.

There are two striking results in Table 1. The first is the large difference in mean response between F24 (which probes the unemployed respondent's notion of a fair wage) and F25 (which asks for his/her reservation wage). This indicates that respondents understand the difference between these two wage-related questions (and hence that the criticism levelled by Kingdon and Knight (2001) against the reservation wage question in the SALDRU survey is probably misplaced).

The second interesting result is that reservation wages for the self-employed and casual workers are substantially higher than those for the unemployed. In the case of casual workers, this probably reflects the effect of scaling up a daily rate to a monthly rate because one would expect daily rates to be higher for short-term jobs. In the case of the self-employed, this may reflect a strong preference for self-employment over other forms of employment.

\section{Table 1. Questions in the KMP Survey pertaining to Reservation Wages}

\begin{tabular}{|c|c|c|}
\hline $\begin{array}{l}\text { Question Number (Number of } \\
\text { respondents who answered) }\end{array}$ & Question & $\begin{array}{l}\text { Mean Rands per } \\
\text { month (median) }\end{array}$ \\
\hline $\begin{array}{l}\mathbf{F} 24 \\
\mathrm{~N}=1,100 \text { unemployed }\end{array}$ & $\begin{array}{l}\text { What do you think would be a reasonable take-home monthly } \\
\text { wage for you given your desired hours of work and your age, } \\
\text { education, skills, and area of residence etc. }\end{array}$ & $\mathrm{R} 1,533$ \\
\hline $\begin{array}{l}\mathrm{F} 25 \\
\mathrm{~N}=1,099 \text { unemployed }\end{array}$ & $\begin{array}{l}\text { What is the absolute minimum take-home monthly wage below } \\
\text { which you would not be prepared to work in any job (taking into } \\
\text { account your desired hours of work)? }\end{array}$ & $\begin{array}{l}\text { R958 } \\
(800)\end{array}$ \\
\hline $\begin{array}{l}\mathrm{G} 29 \\
\mathrm{~N}=208 \text { self-employed }\end{array}$ & $\begin{array}{l}\text { What is the absolute lowest weekly take-home wage you would } \\
\text { accept if offered a job? }\end{array}$ & $\mathrm{R} 2,656$ \\
\hline $\begin{array}{l}\text { I5 } \\
\mathrm{N}=1,241 \text { respondents who would like } \\
\text { to do casual work occasionally }\end{array}$ & $\begin{array}{l}\text { What is the lowest daily take-home wage you would be prepared } \\
\text { to accept for a casual job? }\end{array}$ & $\mathrm{R} 2,319$ \\
\hline $\begin{array}{l}\text { I18 } \\
N=353 \text { respondents who have actually } \\
\text { done casual work in the past six months }\end{array}$ & $\begin{array}{l}\text { What is the lowest daily take-home wage you would be prepared } \\
\text { to accept for a casual job? }\end{array}$ & $\mathrm{R} 2,930$ \\
\hline $\begin{array}{l}\mathrm{K} 5 \\
\mathrm{~N}=2,267 \text { (all respondents) }\end{array}$ & $\begin{array}{l}\text { What is the absolute lowest monthly take home wage that you } \\
\text { would accept for any work (if you were unemployed at the time)? }\end{array}$ & $\begin{array}{l}\mathrm{R} 1,159 \\
(1000)^{2}\end{array}$ \\
\hline
\end{tabular}

In the analysis that follows, K5 is used as the reservation wage measure. Not only did this question have the greatest number of observations, but there are good reasons to believe that $\mathrm{K} 5$ is a reliable measure of reservation wages. Firstly, the mean reservation wage for the employed (R1,319) was (as one would expect) substantially lower than the mean after-tax wage reported by the employed (R1,720). Secondly, for those few (39) 
unemployed respondents who reported having actually turned down wage offers, this was, for the vast majority, consistent with higher reported reservation wages (Nattrass, 2002: 18-23; Walker, 2003: 21-23). Thirdly, the answers of most respondents to K5 are consistent with their responses to hypothetical job offers - i.e. they accepted the offer if the wage was higher than K5, and they rejected it if the wage was lower than K5. This is depicted in more detail in Table 2. Note, however, that an inconsistent answer does not necessarily imply some kind of economic irrationality as the respondent is being asked to consider the type of job as well as the wage. Nevertheless, the fact that answers to $\mathrm{K} 5$ are consistent with the answers given to the hypothetical job offers, suggests that $\mathrm{K} 5$ can be regarded as a reliable measure of reservation wages.

\section{Table 2. Hypothetical Job Offers}

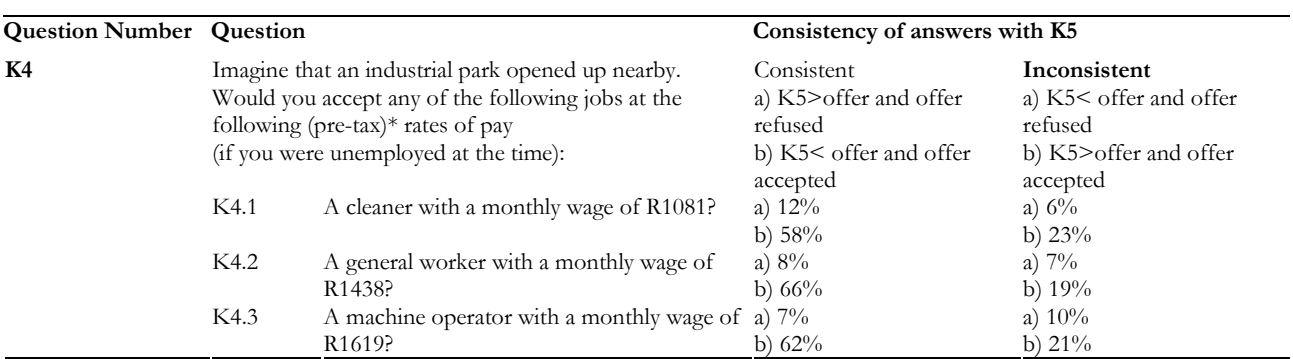

* None of these wages are within a taxable bracket.

Ordinary Least Squares (OLS) regression can help isolate the factors affecting reservation wages for labour-market participants:

$\log ($ reservation wage $)=c+\beta_{1} X_{1}+\beta_{2} X_{2}+\ldots \beta_{i} X_{i}+\varepsilon$

All income variables were logged to control for any scale effects resulting from the wide variation in these variables. Household per capita income was included in the regression model on the grounds that it was probable that job seekers in better-resourced households were less likely to accept low-wage work out of desperation than those living in poorer households. Following Skordis and Welch (2002), household income was estimated by aggregating individual income in the household. This was then divided by household size to obtain per capita household income.

Klasen and Woolard (2000) found that age, gender, race and education had a large and significant impact on reservation wages. We thus included these variables in our analysis.

Duration of unemployment is also likely to matter for reservation wages. However, the relationship between duration of unemployment and reservation wage is complex. If, for example, the long-term unemployed are choosing to stay unemployed longer in order to wait for better job offers, then presumably they have the financial resources to finance this - and thus may report higher reservation wages than the short-term unemployed (Jones, 1988). If, however, the long-term unemployed experience some depreciation in their human capital and adjust their perceptions of their market value accordingly, then there will be a negative relationship between the duration of

\footnotetext{
1 An age-squared variable was included in an earlier regression to test a possible quadratic relationship between age and reservation wage - but was found to be insignificant and discarded from the analysis.
} 
unemployment and the reservation wage (Prasad, 2000:45; Holzer, 1985). But it is also possible that the longer people stay out of wage employment, the less able they become to ascertain their market value correctly. They may thus set unrealistically high reservation wages. In the regression analysis presented here (see Table 3) we include the duration of unemployment in months (logged) and its square in order to test for a possible quadratic relationship between unemployment duration and the reservation wage.

Finally, we included a measure of work experience on the grounds that those who have worked before are in a better labour-market position than those who have not and thus can set higher reservation wages. We created a variable called 'working life' that ranges from 0 (if the respondent reports that he or she has spent no time since leaving school in wage employment) to 4 (the respondent reports that he or she has spent all of his or her time since leaving school in wage employment).

Table 3 presents a set of regressions on the log of the reservation wage. Regression 1 includes all labour-market participants, regression 2 looks at the (broadly defined) unemployed, and regression 3 at the employed (whether wage-employed, self-employed or casual-employed) only. As expected, the regressions show that men have higher reservation wages than women (20\% higher in regression 1), and that older people have higher reservation wages than younger people. Race was also significant in all models, with Coloured respondents having on average reservation wages $25 \%$ higher (regression 1) than Africans. This no doubt in part reflects the legacy of the Coloured Labour Preference policy in the Western Cape (which ensured preferential access to skilled jobs and training opportunities for Coloured workers).

Table 3. Determinants of the (Log of) Reservation Wages

\begin{tabular}{|c|c|c|c|}
\hline Dependent variable: Log of the Reservation Wage & 1. Full sample & 2. Unemployed only & 3. Employed only \\
\hline Age & $\begin{array}{l}0.005^{* * * *} \\
{[0.002]}\end{array}$ & $\begin{array}{l}0.007 * * \\
{[0.003]}\end{array}$ & $\begin{array}{l}0.004^{* *} \\
{[0.002]}\end{array}$ \\
\hline Years of education & $\begin{array}{l}0.034 * * * \\
{[0.006]}\end{array}$ & $\begin{array}{l}0.031 \text { *** } \\
{[0.009]}\end{array}$ & $\begin{array}{l}0.036^{* * *} \\
{[0.007]}\end{array}$ \\
\hline University or technikon education & $\begin{array}{l}0.127 * * \\
{[0.056]}\end{array}$ & $\begin{array}{l}0.069 \\
{[0.090]}\end{array}$ & $\begin{array}{l}0.160^{* *} \\
{[0.072]}\end{array}$ \\
\hline Male/Female & $\begin{array}{l}0.197 * * * \\
{[0.032]}\end{array}$ & $\begin{array}{l}0.162 * * * \\
{[0.050]}\end{array}$ & $\begin{array}{l}0.217 * * * \\
{[0.042]}\end{array}$ \\
\hline Coloured/African & $\begin{array}{l}0.255^{* * *} \\
{[0.036]}\end{array}$ & $\begin{array}{l}0.237 * * * \\
{[0.059]}\end{array}$ & $\begin{array}{l}0.254^{* * *} \\
{[0.047]}\end{array}$ \\
\hline Log of per capita household income & $\begin{array}{l}0.043 * * * \\
{[0.012]}\end{array}$ & $\begin{array}{l}0.041 * * \\
{[0.017]}\end{array}$ & $\begin{array}{l}0.044^{* *} \\
{[0.017]}\end{array}$ \\
\hline Log of duration of unemployment & $\begin{array}{l}-0.122 * * * \\
{[0.036}\end{array}$ & $\begin{array}{l}-0.120^{* * *} \\
{[0.065]}\end{array}$ & \\
\hline Log of duration of unemployment squared & $\begin{array}{l}0.025^{* * *} \\
{[0.008]}\end{array}$ & $\begin{array}{l}0.036 * * * \\
{[0.011]}\end{array}$ & \\
\hline Working life & $\begin{array}{l}0.021^{*} \\
{[0.012]}\end{array}$ & $\begin{array}{l}0.018 \\
{[0.019]}\end{array}$ & $\begin{array}{l}0.022 \\
{[0.015]}\end{array}$ \\
\hline $\mathrm{N}$ & 1499 & 623 & 876 \\
\hline Adjusted R-squared & 0.1694 & 0.1056 & 0.1619 \\
\hline
\end{tabular}

Notes: Numbers in [] are the standard error

* Significant at the $10 \%$ level, ** Significant at the 5\% level, *** Significant at the $1 \%$ level

Working life (i.e. the variable indicating the extent to which respondents spent time since leaving school in wage employment) was marginally significant for the full sample, but not in regressions 2 and 3. Years of education were positively associated with reservation wages in all regressions. Whether the respondent had a university or technical education mattered for the full sample (employed plus unemployed) and for the employed, but did not exercise a statistically significant impact on the reservation 
wages of the sample containing only the unemployed.

Duration of unemployment exercised a negative impact on the reservation wage although the significance of the quadratic term indicates that the relationship turned positive for the very long-term unemployed. This is consistent with the hypothesis that reservation wages decline as the duration of unemployment increases (maybe because people become increasingly desperate and/or discount their human capital over time) but that this relationship changes its sign for the very long-term unemployed (perhaps because they lose perspective as to what an appropriate reservation wage is for them). It is also possible that the long-term unemployed with high reservation wages are those who can 'afford' to be unemployed. However, given Kingdon and Knight's (2001) compelling case against the 'luxury unemployment' hypothesis, this proposition seems implausible as a general explanation.

Per capita household income was significantly related to the reservation wage, thus suggesting that those living in better-resourced households were probably less desperate than those living in poorer households, and thus could set higher reservation wages.

Interesting though it may be, the discussion so far has yet to shed any light on the question as to whether reservation wages in KMP are 'too high' or not. To address this question, we need to examine reservation wages in relation to predicted wages.

\section{RESERVATION WAGES AND PREDICTED WAGES}

One way of exploring whether a person's reservation wage (RW) is 'out of line' with his or her market value is to divide it by his or her predicted wage (PW) based on personal characteristics. Those who have a value greater than 1 could be said to be manifesting unrealistic wage expectations.

Unlike Kingdon and Knight (who generated predicted wages for unemployed individuals using parameters from the wage functions of employed persons), we opted to use a Heckman maximum likelihood model to generate predicted wages for all respondents in the KMP survey. This method entails running an initial probit model to predict which respondents would be employed given certain characteristics. Our working hypothesis for this 'selection stage' of the model was that social capital matters for obtaining work - hence the inclusion of 'head of household' and 'urban/rural background' ${ }^{2}$ as explanatory variables. In regression models 1 and 2, we include age, education, gender and race as other relevant variables affecting the probability of finding a wage job.

Once the likelihood function is specified, the Heckman selection methodology then seeks to find a set of parameters that maximises the likelihood function and generates predicted wages for all respondents. We included age and working life as proxies for experience as explanatory variables in this 'outcome' stage. In regression models 1 and 3 , we also included gender, race and education (as is typical of wage determination models for the South African labour market - see e.g. Chamberlain and Van der Berg (2002)).

\footnotetext{
2 As Standing pointed out some time ago, migrants "are likely to have less knowledge of prevailing urban wage rates and, possibly with fewer income-sharing contacts on whom to rely, a greater need for an income from work, however small" (1978:233). This suggests that a person from a rural area will have a lower probability of securing employment (lack of contacts, urban labour-market experience etc.).
} 
Table 4 presents three alternative specifications. Model 1 includes race and gender in both the selection and outcome stages, and models 2 and 3 include race and gender only in the selection and outcome stages respectively. Note that race and gender are statistically significant in models 2 and 3, but that once they appear in both the outcome and selection stages (model 1) these variables are statistically significant only in the selection stage. As it seems plausible that gender and race matter both in terms of getting a job and determining wages, we opted for model 1 when determining the predicted wages to be used later on in the analysis.

Table 4. The Heckman Maximum Likelihood Model

\begin{tabular}{|c|c|c|c|}
\hline Dependent Variable: $\ln ($ wage) & 1 & 2 & 3 \\
\hline \multicolumn{4}{|l|}{ SELECTION STAGE } \\
\hline Intercept & $\begin{array}{l}-1.940^{* * *} \\
{[0.165]}\end{array}$ & $\begin{array}{l}-1.950^{* * *} \\
{[0.163]}\end{array}$ & $\begin{array}{l}-1.682^{* * *} \\
{[0.156]}\end{array}$ \\
\hline Age & $0.017^{* * *}$ & $0.018^{* * *}$ & $-0.017^{* * *}$ \\
\hline Male/female & $\begin{array}{l}{[0.003]} \\
0.379^{* * *}\end{array}$ & $\begin{array}{l}{[0.003]} \\
0.395^{* * *}\end{array}$ & {$[0.003]$} \\
\hline Years of education & $\begin{array}{l}{[0.063]} \\
0.062 * * *\end{array}$ & $\begin{array}{l}{[0.052]} \\
0.063 * * *\end{array}$ & $0.057 * * *$ \\
\hline & {$[0.010]$} & {$[0.010]$} & {$[0.010]$} \\
\hline Race & $\begin{array}{l}0.418^{* * *} \\
{[0.078]}\end{array}$ & $\begin{array}{l}0.417 * * * \\
{[0.066]}\end{array}$ & \\
\hline Head of household & $\begin{array}{l}0.331 * * * \\
{[0.059]}\end{array}$ & $\begin{array}{l}0.331 * * * \\
{[0.059]}\end{array}$ & $\begin{array}{l}0.387 * * * \\
{[0.057]}\end{array}$ \\
\hline Urban/rural background & $\begin{array}{l}0.135^{* *} \\
{[0.059]}\end{array}$ & $\begin{array}{l}0.135^{* *} \\
0.059\end{array}$ & $\begin{array}{l}0.279 * * * \\
{[0.051]}\end{array}$ \\
\hline Censored & 1155 & 1155 & 1161 \\
\hline Uncensored & 701 & 701 & 701 \\
\hline $\log \mathrm{L}$ & -1848.004 & -1848.139 & -1886.381 \\
\hline OUTCOME STAGE & & & \\
\hline Intercept & $\begin{array}{l}7.955^{* * *} \\
{[0.224]}\end{array}$ & $\begin{array}{l}7.982^{* * *} \\
{[0.205]}\end{array}$ & $\begin{array}{l}7.880 * * * \\
{[0.217]}\end{array}$ \\
\hline Age & $\begin{array}{l}-0.009^{* * *} \\
{[0.003]}\end{array}$ & $\begin{array}{l}-0.009^{* * *} \\
{[0.003]}\end{array}$ & $\begin{array}{l}-0.010^{* *} \\
{[0.003]}\end{array}$ \\
\hline Male/female & $\begin{array}{l}0.028 \\
{[0.071]}\end{array}$ & & $\begin{array}{l}0.274 * * * \\
0.053\end{array}$ \\
\hline Coloured/African & $\begin{array}{l}-0.022 \\
{[0.073]}\end{array}$ & & $\begin{array}{l}0.206^{* * *} \\
{[0.058]}\end{array}$ \\
\hline Years of education & $\begin{array}{l}0.024 * * \\
{[0.011]}\end{array}$ & $\begin{array}{l}0.022 * * \\
{[0.011]}\end{array}$ & $\begin{array}{l}0.021 * \\
0.011\end{array}$ \\
\hline Working life & $\begin{array}{l}0.065^{* * *} \\
{[0.020]}\end{array}$ & $\begin{array}{l}0.065^{* * *} \\
{[0.020]}\end{array}$ & $\begin{array}{l}0.062^{* * *} \\
{[0.020]}\end{array}$ \\
\hline Lambda & $\begin{array}{l}-0.974^{* * *} \\
{[0.052]}\end{array}$ & $\begin{array}{l}-0.977^{* * * *} \\
{[0.048]}\end{array}$ & $\begin{array}{l}-0.999 * * * \\
{[0.052]}\end{array}$ \\
\hline $\mathrm{N}$ & 1856 & 1856 & 1862 \\
\hline Wald chi2 & 29.09 & 28.75 & 72.99 \\
\hline Prob $>$ chi2 & 0.000 & 0.000 & 0.000 \\
\hline Likelihood ratio test chi2 & 74.10 & 131.14 & 77.69 \\
\hline Prob $>$ chi2 & 0.000 & 0.000 & 0.000 \\
\hline $\begin{array}{l}\% \text { with } \mathrm{RW} / \mathrm{PW}>1 \\
(95 \% \text { confidence interval) } \\
\text { Mean (RW/PW) } \\
(95 \% \text { confidence interval) }\end{array}$ & $\begin{array}{l}3.2 \% \\
(2.5 \%-4.0 \%) \\
86.2 \% \\
(85.8 \%-86.5 \%)\end{array}$ & $\begin{array}{l}3.3 \% \\
(2.5 \%-4.1 \%) \\
86.2 \% \\
(85.8 \%-86.5 \%)\end{array}$ & $\begin{array}{l}2.5 \% \\
(1.8 \%-3.2 \%) \\
86.0 \% \\
(85.6 \%-86.3 \%)\end{array}$ \\
\hline
\end{tabular}

Notes: Numbers in [] are the standard error

* Significant at the $10 \%$ level, ** Significant at the $5 \%$ level, *** Significant at the $1 \%$ level

The likelihood ratio test for model 1 produced a chi-squared statistic of 74.10. Thus, at the $1 \%$ level one is able to reject the hypothesis that the selection and outcome stages are independent. This supports the use of the Heckman approach in generating predicted wages. Predicted wages were generated for all respondents (using model 1 in 
Table 4) including those presently in wage-employment. The predicted wages were adjusted by the inverse mills ratio (lambda), to account for the probability of the person getting the job.

A ratio of reservation wage to predicted wage (RW/PW) was then calculated for each respondent. As reported in Tables 4 and 5, the mean RW/PW for the total sample was 0.862 . Only $3.2 \%$ (with a $95 \%$ confidence interval of $2.5 \%-4.0 \%$ around this estimate) of respondents had RW/PW ratios greater than 1. Table 4 shows that the three different specifications of the Heckman selection model produced similar results in terms of the mean RW/PW and the proportion of respondents with RW/PW>1.

Table 5. Reservation $W$ ages $(\mathrm{RW})$ and Predicted $W$ ages $(\mathrm{PW})$

\begin{tabular}{lllll}
\hline & RW/PW & & \% with RW>PW & \\
& Mean & $95 \%$ confidence interval & Mean & $95 \%$ confidence interval \\
Wage employed & $87.5 \%$ & $87.0 \%-88.0 \%$ & $4.3 \%$ & $2.8 \%-5.6 \%$ \\
Self-employed & $86.7 \%$ & $85.2 \%-88.1 \%$ & $6.6 \%$ & $2.6 \%-10.6 \%$ \\
Casual employed & $85.8 \%$ & $83.6 \%-88.0 \%$ & $1.6 \%$ & $-1.6 \%-4.9 \%$ \\
Total employed & $87.3 \%$ & $86.8 \%-87.8 \%$ & $4.5 \%$ & $3.2 \%-5.8 \%$ \\
Search unemployed & $85.5 \%$ & $84.8 \%-86.3 \%$ & $1.3 \%$ & $0.2 \%-2.4 \%$ \\
Network searching unemployed & $84.7 \%$ & $83.6 \%-86.0 \%$ & $0.6 \%$ & $-0.6 \%-1.9 \%$ \\
Marginalised unemployed & $84.4 \%$ & $83.4 \%-85.4 \%$ & $1.7 \%$ & $2.2 \%-3.2 \%$ \\
Total Unemployed & $85.0 \%$ & $84.4 \%-85.5 \%$ & $1.3 \%$ & $0.5 \%-2.1 \%$ \\
Non labour force participants & $90.4 \%$ & $88.7 \%-92.1 \%$ & $9.1 \%$ & $1.3 \%-16.9 \%$ \\
Total & $86.2 \%$ & $85.8 \%-86.6 \%$ & $3.2 \%$ & $2.5 \%-4.0 \%$ \\
\hline
\end{tabular}

Table 5 provides information on mean RW/PW ratios (generated by regression 1 in Table 4) by labour-market status. The over-lapping confidence intervals for the mean RW/PW ratios for different kinds of employment and unemployment indicate that the differences were not statistically significant within these two broad categories. However, the mean RW/PW for the (total) unemployed was statistically significantly lower than that for the (total) employed. The unemployed as a whole also had a statistically significantly lower mean PW/PW ratio than was the case for the wage employed. This suggests that the unemployed have adjusted their reservation wages downwards relative to their employed counterparts.

Table 6. RW/PW and the Probability of being Unemployed as Opposed to Wage Employed

\begin{tabular}{|c|c|}
\hline \multicolumn{2}{|c|}{ Dependent variable: probability of being unemployed as opposed to wage employed } \\
\hline Intercept & $\begin{array}{l}2.076^{* * *} \\
{[0.203]}\end{array}$ \\
\hline Age & $\begin{array}{l}-0.021^{* * *} \\
{[0.004]}\end{array}$ \\
\hline Male/female & $\begin{array}{l}-0.313^{* * *} \\
{[0.074]}\end{array}$ \\
\hline Years of education & $\begin{array}{l}-0.084^{* * *} \\
{[0.012]}\end{array}$ \\
\hline Coloured/African & $\begin{array}{l}-0.452^{* * *} \\
{[0.075]}\end{array}$ \\
\hline Household head & $\begin{array}{l}-0.633^{* * *} \\
{[0.083]}\end{array}$ \\
\hline Urban/rural background & $\begin{array}{l}0.029 \\
{[0.089]}\end{array}$ \\
\hline $\mathrm{RW} / \mathrm{PW}$ dummy (taking the value of 1 if $\mathrm{RW} / \mathrm{PW}>1$ and 0 if $\mathrm{PW} / \mathrm{PW}<1$ & $\begin{array}{l}-0.522 * * \\
{[0.251]}\end{array}$ \\
\hline $\mathrm{N}$ & 1491 \\
\hline $\log \mathrm{L}$ & -901.421 \\
\hline LR chi2 & 253.29 \\
\hline Prob $>$ chi2 & 0.000 \\
\hline 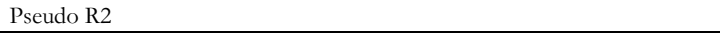 & 0.1232 \\
\hline
\end{tabular}


Table 6 explores the relationship between the RW/PW ratio and unemployment further by including RW/PW as an explanatory variable in a regression on the probability of being unemployed (as opposed to being wage employed). It shows that controlling for age, gender education and race, RW/PW ratios of higher than 1 are associated with statistically significantly lower chances of being unemployed. This adds further support for the argument made earlier: that there is no evidence that relatively high RW/PW ratios are a cause of unemployment in Khayelitsha/Mitchell's Plain.

\section{CONCLUSION}

In conclusion it is important to stress that this analysis is specific to working class Cape Town and cannot be generalised to the country as a whole. The analysis is nevertheless instructive in that it is based on an innovative data set that was designed specifically to probe some of the puzzling aspects of South African unemployment - including the issue of reservation wages. The survey showed that people's understandings of reservation wage questions varied significantly depending on how the question was phrased - thus highlighting once again the need for careful survey design and piloting. The fact that the reservation wage question used in the analysis presented here was consistent with responses to hypothetical job offers (see Table 2) indicates that the question was understood largely as intended (and hence that the data is meaningful).

Our analysis of the RW/PW ratio showed that the overwhelming majority of respondents had ratios of less than 1 - i.e. their reservation wages were lower than their predicted wages (as generated by a Heckman selection model). Other model specifications would no doubt generate different results. However, the fact that over $95 \%$ of respondents had predicted wages higher than their reservation wages (and that this was true for all three specifications presented in Table 4), is extremely interesting. At the very least, it suggests that there is no support for the proposition that unemployment should be categorised as 'voluntary', in working class Cape Town. Rather, it appears that people's reservation wages are realistic given what they could expect to earn in the labour market.

\section{REFERENCES}

BABER, R. (1998). The Structure of Livelihoods in South Africa's Bantustans: Evidence from Two Settlements in Northern Province, Pd.D. Dissertation, Oxford University.

Chamberlain, D. AND S. VAN DeR BerG. (2002). "Earnings Functions, Labour Market Discrimination and Quality of Education in South Africa," Bureau for Economic Research, Department of Economics, University of Stellenbosch, Working Paper 2/2002.

Crankshaw, O., Welch, M. And S. Butcher. (2001). "GIS Technology and Survey Sampling Methods: The Khayelitsha/Mitchell's Plain 2000 Survey” in Social Dynamics, 27(2): 156-174.

DiAS, R. (2002). "Exploring the Nature of Unemployment in South Africa: Insights from the Labour Force Survey 2000," Division of Economics, University of Natal, Durban. Paper presented at the Development Policy Research Unit's $2^{\text {nd }}$ Annual Conference on Labour Markets and Poverty in South Africa, September.

Dinkelman, T. AND F. Pirouz. (2001). "Individual, Household and Regional Determinants of Labour Force Attachment in South Africa: Evidence from the 1997 October Household Survey”, TIPS Working Paper, 1-2001. Trade and Industrial Policy Secretariat, TIPS.

_ (2004). "How Household Context Affects Search Outcomes of the Unemployed in KwaZulu Natal, South Africa: A Panel Data Analysis", in South African Journal of Economics, vol.72, no.3.

DuFF, P. AND D. FrYER. (2004). "The Dynamics of Job Search and the Microfoundations of Unemployment: Evidence from Duncan Village", paper presented at the DPRU Conference, African Development and Poverty Reduction: The Micro-Macro Linkage, Cape Town.

HeckMAn, J.J. (1979). "Sample Selection Bias as a Specification Error," Econometrica,Vol. 47(1): 153-161.

Holzer, H.J. (1985). "Reservation Wages and their Labour Market Effects for Black and White Male Youth," Journal of Human Resources, XXI: 157-177. 
ICLS. (1982). Resolution concerning statistics of the economically active population, employment, unemployment and underemployment, adopted by the Thirteenth International Conference of Labour Statisticians (October 1982). Available on: http://www.ilo.org/public/english/bureau/stat/res/ecacpop.htm.

JONES, S. (1988). "The relationship between unemployment spells and reservationwages as a test of search theory," Quarterly Journal of Economics, Vol. 103: 741-765.

KillingsworTh, M. (1983). "Labour Supply," Cambridge Surveys of Economic Literature, Cambridge University Press. KIngDON, G. AND J. KNIGHT. (2000). "Are Searching and Non-searching Unemployment Distinct States when Unemployment is High? The Case of South Africa," Centre for the Study of African Economies, Department of Economics, University of Oxford.

and _ (2001). "Unemployment in South Africa: the nature of the beast," Centre for the Study of African Economies, Department of Economics, University of Oxford.

KLASEN, S. AND WOOLARD, I. (2000). "Surviving Unemployment without StateSupport: Unemployment and Household Formation in South Africa," IZA Discussion Paper No. 237, Bonn.

LEIBBRANDT, M., BHORAT, H. AND I. WOOLARD. (2001). "Household Inequality and the Labour Market in South Africa," Contemporary Economic Policy, 19(1): 73-87.

AND I. WOOLARD. (2001). "The Labour Market and Household Income Inequality in South Africa: Existing Evidence and New Panel Data," Journal of International Development, 13:671-689.

NATTRASS, N. (2000). "The Debate about Unemployment in the 1990s," Studies in Economics and Econometrics, Vol. 24, No. 3: 73-90.

(2002). Unemployment, Employment and Labour-Force Participation in Khayelitsha/ Mitchell's Plain. CSSR Working Paper no. 12. Available on www.cssr.uct.ac.za

PRASAD, E.2. (2000). "The Dynamics of Reservation Wages: Preliminary Evidencefrom the GSOEP," Research Department, IMF. Prepared for the GSOEP (German Socio-economic panel)Conference in Berlin, July 4-6.

SAPSFORD, D. AND Z. TZANNATOS. (1993). “The Economics of the Labour Market,”London: MacMillan,

SCHÖER, V. (2004). "Job Search Strategies and Social Networks: Evidence from the Khayelitsha/Mitchell's Plain Survey", Master's Thesis, University of Cape Town.

SEEKINGS, J. (2003)a. Social Stratification and Inequality at the End of Apartheid. Working Paper no.31. Cape Town: Centre for Social Science Research, University of Cape Town.

(2003b). Do South Africa's Unemployed Constitute an Underclass?”, CSSR Working Paper no.32. Available on www.cssr.uct.ac.za

_ and N. NATTRASS (forthcoming, 2005). Class, Race and Inequality in South Africa, Yale University Press, New Haven.

SkORDIS, J. AND M. WELCH. (2002). "Comparing Alternative Measures of Household Income: Evidence from the Khayelitsha/Mitchell's Plain Survey," CSSR Working Paper No. 25, Centre for Social Science Research, University of Cape Town.

StAnding, G., SENDER, J. And J. WeEks. (1996). The South African Challenge: Restructuring the South African Labour Market, Geneva, International Labour Organisation.

_ (1978). "Aspiration Wages, Migration and Urban Unemployment," Journal of Development Studies, Vol.14, No. 2, January: 232-249.

Walker, R. (2003). "Reservation Wages: Measurement and Determinants: Evidence from the Khayelitsha/Mitchell's Plain Survey, CSSR Working Paper, no.38, Centre for Social Science Research, University of Cape Town. Available on www.cssr.uct.ac.za

WitTENBERG, M. (1999). "Job Search and Household Structure in an Era of Mass Unemployment: A Semi-parametric Analysis of the South African Labour Market", ERSA Working Paper no.3, University of the Witwatersrand, Johannesburg.

_ (2001). "Spatial Dimensions of Unemployment", conference paper at DPRU/FES Conference on Labour Markets and Poverty in South Africa, Johannesburg. 